\title{
Pembangunan Agrowisata Showfarm
}

\author{
Murni \\ Syaribulan K \\ Universitas Muhammadiyah Makassar \\ syaribulan@unismuh.ac.id
}

\begin{abstract}
ABSTRAK
Penelitian yang dilaksanakan di Kecamamata Ulu Ere Kabupaten Bantaeng merupakan Jenis penelitian yang menggunakan metode penelitian deskriptif kualitatif dengan sasaran penelitian 10 orang berdasarkan tingkatan umur dari 25 sampai 62 tahun dengan memilih beberapa informan yang memiliki kriteria yang telah ditentukan oleh peneliti yakni masyarakat setempat yang ada disekitar pembangunan agrowisata showfarm yang mengalami perubahan di Kecamatan Ulu Ere Kabupaten Bantaeng.Penelitian ini bertujuan untuk mengetahui tanggapan masyarakat terhadap program agrowisata showfarm di Kecamataan Ulu Ere, dan untuk megetahui dampak agrowisata showfarm terhadap perubahan sosial ekonomi masyarakat di kecamatan Ulu Ere Kabupaten Bantaeng.Dari hasil penelitian menunjukan bahwa tanggapan masyarakat mengenai program pembangunan agrowisata showfarm sangat baik dan dianggap suatu tempat wisata yang membawa keuntungan bagi masyarakat, dengan adanya agrowisata masyarakat setempat bisa berkenalan para pejabat atau pemerintah yang berkunjung. Adapun dampak yang ditimbulkan oleh agrowisata showfarm yaitu sebagai berikut:Dampak positif yaitu: a). Dapat memperkenalkan hasil panen tanpa mengurangi biaya transfortasi b). Tempat perkumpulan para pemuda dan pemudi c). Sebagai salah satu lapangan pekerjaan d). Sering bertemu bapak bupati bantaeng e). Tempat rekreasi
\end{abstract}

Kata Kunci : Perubahan Sosial, Pembangunan, Agowisata.

\section{PENDAHULUAN}

Hakekat dan makna perkembangan pada suatu mahluk hidup atau organisme adalah sesuatu yang niscaya dan alami (natural). Artinya setiap mahluk hidup pasti dan tidak dapat menghindari dari berlangsungnya proses perkembangan pada dirinya yang umumnya dikategorikan seperti kelahiran, masa berkembang dan kematian. Dengan kata lain, perkembangan yang dialami setiap mahluk hidup berlangsung semenjak ia dilahirkan hingga ia mengalami kematian. Sebagai suatu proses, perkembangan berisi rentetan tahap-tahap kematangan. Kata perkembangan seringkali dikaitkan dengan pertumbuhan. Keduanya memang mempunyai hubungan yangsangat erat seperti dijelaskan Sukmadinata (2003: 72). Pertumbuhan dan perkembangan hakekatnya adalah perubahan, yaitu perubahan ke arah yang lebih tinggi atau lebih baik. Dapat diartikan perubahan yang ada pada mahluk hidup merupakan bagian dari pertumbuhan fisik dan 
perkembanagan psikis atau rohaninya. Manusia sebagai salah satu mahluk yang mendiami bumi. selama hidup pasti mengalami perubahan. Dimulai dari anak-anak, remaja, dewasa dan menua manusia normal mengalami perkembangan baik pada fisik dan psikisnya. Perubahan yang dialami manusia secara person (individu) dipengaruhi oleh faktor lingkungan tempat dimana ia hidup. Lingkungan tersebut dapat berupa lingkungan internal seperti keluarga dan eksternal yaitu alam, masyarakat serta budayanya.

Pembangunan sepertinya sebagai suatu fenomena yang tidak habis-habisnya dibahas dalam kerangka kajian keberlangsungan hidup manusia. Fenomena ini melekat sebagai salah satu ciri kehidupan manusia yang kerap mengalami perubahan menurut berbagai dimensi yang ada. Konsep pembangunan biasanya melekat dalam konteks kajian suatu perubahan, pembangunan disini diartikan sebagai bentuk perubahan yang sifatnya direncanakan, setiap orang atau kelompok orang tentu akan mengharapkan perubahan yang mempunyai bentuk lebih baik bahkan sempurna dari keadaan yang sebelumnya untuk mewujudkan harapan ini tentu harus memerlukan suatu perencanaan.Agrowisata Showfarm merupakan suatu tempat perkenalan hasil pertanian masyarakat setempat yang terletak di wilayah Kecamatan Ulu Ere, Kabupaten Bantaeng dan seringkali dikunjungi oleh para wisatawan dari luar baik dari wisatawan lokal maupun dari manca negara. Keberadaan Agrowisata tersebutsedikit banyak mempengaruhi faktor perekonomian masyarakat setempat.

\section{LANDASAN TEORI}

Pada dasarnya setiap masyarakat yang ada di muka bumi ini dalam hidupnya dapat dipastikan akan mengalami apa yang dinamakan dengan perubahan. Adanya perubahan tersebut akan dapat diketahui bila dilakukan suatu perbandingan dengan menelaah suatu masyarakat pada masa tertentu yang kemudian kita bandingkan dengan keadaan masyarakat pada waktu yang lampau. Perubahan yang terjadi di dalam masyarakat, pada dasarnya merupakan suatu proses yang terus menerus, ini berarti bahwa setiap masyarakat kenyataannya akan mengalami perubahan-perubahan. Tetapi perubahan yang terjadi antara masyarakat yang satu dengan masyarakat yang lain tidak selalu sama. Hal ini di karenakan adanya suatu masyarakat yang mengalami perubahan yang lebih cepat bila dibandingkan dengan masyarakat lainnya. Perubahan tersebut dapat berupa perubahan yang tidak menonjol atau tidak menampakkan adanya suatu perubahan yang terjadi di masyarakat. Juga terdapat adanya perubahan yang memiliki pengaruh 
yang luas maupun yang terbatas. Disamping itu juga ada perubahan yang prosesnya lambat, dan ada juga perubahan yang prosesnya berlangsung dengan cepat.Setiap manusia selama hidup pasti mengalami yang namanya perubahan. Adapun perubahan dapat berupa pengaruhnya terbatas maupun luas, perubahan yang lambat dan ada juga perubahan yang berjalan dengan cepat. Perubahan dapat mengenai nilai dan norma sosial, pola perilaku organisasi, susunan lembaga kemasyarakatan, dan lapisan dalam masyarakat, kekuasaan dan wewenang, interaksi sosial dan lain sebagainya. Adapun perubahan yang terjadi pada masyarakat merupakan gejala yang normal. Pengaruhnya bisa menjalar dengan cepat ke bagian-bagian dunia lain berkat adanya komunikasi modern. Perubahan dalam masyarakat telah ada sejak zaman dahulu. Namun, sekarang perubahan berjalan dengan sangat cepat sehingga dapat membingungkan manusia yang menghadapinya.Perubahan sosial merupakan gejala yang melekat di setiap masyarakat. Perubahan-perubahan yang terjadi di dalam masyarakat akan menimbulkan ketidaksesuaian antara unsur-unsur sosial yang ada di dalam masyarakat, sehingga menghasilkan suatu pola kehidupan yang tidak sesuai fungsinya bagi masyarakat yang bersangkutan.Kingslay Davis (dalam Soekanto; 1982) mengartikan perubahan sosial sebagai perubahan-perubahan yang terjadi dalam struktur dan fungsi masyarakat. Misalnya, munculnya pengorganisasian buruh dalam masyarakat kapitalis telah menyebabkan perubahan-perubahan dalam hubungan antara buruh dengan majikan dan seterusnya menyebabkan perubahan-perubahan dalam organisasi ekonomi dan politik. Maclver (dalam Soekanto; 1982) perubahan-perubahan sosial dikatakannya sebagai perubahan-perubahan dalam hubungan sosial (social relationship) atau sebagai perubahan terhadap keseimbangan (equilibrium) hubungan sosial. William F. Ogburn (dalam Setiadi. dkk; 2006) mengemukakan bahwa ruang lingkup perubahan sosial mencakup unsur-unsur kebudayaan yang materil maupun immaterial dengan menekankan bahwa pengaruh yang besar dari unsur-unsur immaterial. Sedangkan Menurut Selo Soemardjan, (Setiadi. dkk; 2006) Perubahan sosial adalah perubahan yang terjadi pada lembaga kemasyarakatan di dalam suatu masyarakat yang memengaruhi sistem sosial, termasuk di dalam nilai-nilai, sikap-sikap, dan pola perilaku di antara kelompok dalam masyarakat. Menurutnya, antara perubahan sosial dan perubahan kebudayaan memiliki satu aspek yang sama yaitu keduanya bersangkut paut dengan suatu penerimaan cara-cara baru atau suatu perbaikan cara masyarakat dalam memenuhi kebutuhannya. Perubahan sosial yaitu perubahan yang terjadi dalam masyarakat atau dalam hubungan interaksi, yang meliputi berbagai aspek kehidupan. Sebagian akibat adanya dinamika anggota masyarakat dan 
yang telah didukung oleh sebagian besar anggota masyarakat merupakan tuntutan kehidupan dalam mencarikestabilannya.

Ditinjau dari tuntutan stabilitas kehidupan perubahan sosial yang dialami oleh masyarakat adalah hal yang wajar. Kebalikannya masyarakat yang tidak berani untuk melakukan perubahan tidak akan dapat melayani tuntutan dan dinamika anggota-anggota yang selalu berkembang kemauan dan aspirasinya.Istilah community dapat diterjemahkan sebagai "masyarakat setempat" yang menunjukkan pada warga sebuah desa, kota, suku, atau bangsa. Apabila anggota-anggota suatu kelompok, baik kelompok itu besar maupun kecil, hidup bersama sedemikian rupa sehingga merasakan bahwa kelompok tersebut dapat memenuhi kepentingan-kepentingan hidup yang utama, perkembangan akibat adanya pertentangan antara kelompok-kelompok yang terbagi secara ekonomi.Masyarakat adalah sebuah komunitas yang interdependen (saling tergantung satu sama lain). Umumnya, istilah masyarakat digunakan untuk mengacu sekelompok orang yang hidup bersama dalam satu komunitas yang teratur. Dimana sebagian besar interaksi adalah antara individu-individu yang berada dalam kelompok tersebut. Melihat dari berbagai aspek kehidupan yang terjadi di masyarakat pada saat ini, masih terjadinya beberapa fenomena pergeseran nilai, norma serta adat istiadat kaitannya dengan pemahaman tentang masyarakat desa dan kota. Hal tersebut dapat ditinjau dari ilmu sosiologi, dimana yang menjadi obyek adalah masyarakat yang dilihat dari hubungan antar manusia, dan proses yang timbul dari hubungan manusia di dalam masyarakat.

Pembangunan sebenarnya meliputi dua unsur pokok; pertama, masalah materi yang mau dihasilkan dan dibagi, dan kedua, masalah manusia yang menjadi pengambil inisiatif, yang menjadi manusia pembangun. Bagaimanapun juga, pembangunan pada akhirnya harus ditujukan pada pembangunan manusia; manusia yang dibangun adalah manusia yang kreatif, dan untuk bisa kreatif ini manusia harus merasa bahagia, aman, dan bebas dari rasa takut. Pembangunan tidak hanya berurusan dengan produksi dan distribusi barang-barang material; pembangunan harus menciptakan kondisi-kondisi manusia bisa mengembangkan kreatifitasnya. Pembangunan pada hakekatnya adalah suatu proses transformasi masyarakat dari suatu keadaan pada keadaan yang lain yang makin mendekati tata masyarakat yang dicita-citakan; dalam proses transformasi itu ada dua hal yang perlu diperhatikan, yaitu keberlanjutan (continuity) dan perubahan (change), tarikan antara keduanya menimbulkan dinamika dalam perkembangan masyarakat.W.W.Rostow, seorang ekonom Amerika serikat, menjadi bapak teori pembangunan dan pertumbuhan. Teorinya mempengaruhi model pembangunan di hampir semua dunia ketiga. Fikiran 
Rostow pada dasarnya di kembangkan dalam kontex peran dingin serta membendung pengaruh sosialisme. Itulah makanya fikiran Rostow pertama dituangkan dalam makalah dengan secara jelas sebagai manifesto non komunis. Dalam tulisan yamg berjudul The Stanges of Economic Growth: A Non- Communist Manifest, Rostow membentangkan pandangannya tentang modernisasi yang di anggapanya sebagai cara untuk membendung semangat sosialisme. Teori Rostow tentang pertumbuhan pada dasarnya merupakan sebuah versi dari teori modernisasi dan pembangunan, yakni suatu teori yang meyakini bahwa faktor manusia (bukan struktur dan sistem) menjadi fokus utama perhatian mereka. Teori pertumbuhan adalah suatu bentuk teori modernisasi yang menggunakan metafora pertumbuhan, yakni sebagai organisme. Rostow melihat perubahan sosial, yang disebut sebagai pembangunan, sebagai proses evolusi perjalanan dari tradisional ke modern. Fikiran pertumbuhan ini dijelaskan secar rinci oleh Rostow (1960) yang sangat terkenal yankni The fife-stageschmem. Asumsinya adalah bahwa bahwa semua masyarakat termasuk masyarakat barat pernah mengalami ' tradisional' dan akhirnya menjadi 'modern'sikap manusia tradisional dianggap sebagai masalah. Seperti pandangan Rostow dan pengikutnya, development makna berjalan secara hampir optimis melalui akumulasi modal (tabungan dan investasi) dengan tekanan bantuan dan hutan luar negeri . dia menfokuskan pada perlunya elite wiraswasta yang menjadi motor proses itu.

Di Indonesia, Agrowisata atau agroturisme didefinisikan sebagai sebuah bentuk kegiatan pariwisata yang memanfaatkan usaha agro (agribisnis) sebagai objek wisata dengan tujuan untuk memperluas pengetahuan, pengalaman, rekreasi dan hubungan usaha di bidang pertanian. Melalui pengembangan agrowisata yang menonjolkan budaya lokal dalam memanfaatkan lahan, diharapkan bisa meningkatkan pendapatan petani sambil melestarikan sumber daya lahan, serta memelihara budaya maupun teknologi lokal (indigenous knowledge) yang umumnya telah sesuai dengan kondisi lingkungan alaminya.Sutjipta (2001) mendefinisikan, agrowisata adalah sebuah sistem kegiatan yang terpadu dan terkoordinasi untuk pengembangan pariwisata sekaligus pertanian, dalam kaitannya dengan pelestarian lingkungan, peningkatan kesajahteraan masyarakat petani.Agrowisata dapat dikelompokkan ke dalam wisata ekologi (eco-tourism), yaitu kegiatan perjalanan wisata dengan tidak merusak atau mencemari alam dengan tujuan untuk mengagumi dan menikmati keindahan alam, hewan atau tumbuhan liar di lingkungan alaminya serta sebagai sarana pendidikan (dalam Deptan; 2005).Showfarm merupakan suatu tempat Agrowista yang memperkenalkan hasil pertanian para 
masyarakat setempat, didalam Agrowisata tersebut terdapat sayuran dan buah-buahan sebagai ciri khas hasil pertanian Kecamatan Ulu Ere Kabupaten Bantaeng.

\section{METODE PENELITIAN}

Dalam penelitian yang berjudul "Perubahan Sosial Ekonomi Masyarakat di Kecamatan Ulu Ere Kabupaten Bantaeng (studi Pembangunan Agrowisata Showfarm ini dengan menggunakan penelitian deskriptif kualitatif yaitu suatu penelitian yang menghasilkan data-data deskriptif berupa kata-kata yang berbetuk tulisan atau lisan dari individu dan mengarahkan pada tingkah laku yang dialami.Penentuan informan harus ditentukan melalui metode pengambilan sampel dan metode penarikan sampel yang di gunakan dalam penelitian ini adalah teknik snowballSampling. Snowball menurut asalkata berarti bola saju yang prinsipnya semakin menggelinding semakin besar, pengambilan sampel yang mulanya satu orang sebagai key informan akan berkembang sesuai petunjuknya informan tersebut hingga didapati informan yang lain. Dengan perkataan lain peneliti awalnya mempertimbangkan orang tertentu dalam memberikan data yang diperlukan, selanjutnya berdasarkan data atau inforamasi yang diperoleh dari sampel tersebut peneliti dapat menetapkan sampel lainnya yang akan dipertimbangkan akan memberikan data lebih lengkap dari sampel tersebut tadi. Dalam hal ini peneliti hanya mengungkapakan kriteria sebagai prasyarat dapat dijadikan sampel. Teknik pengumpulan data yaitu observasi, wawancara dan dokumentasi dan menggunakan teknik keabsahan data melalui validasi, Realibilitas, dan Obyektivitas

\section{PEMBAHASAN}

Perubahan sosial telah membuka pola pemikiran masyarakat dengan pembangunan agrowisata showfarm, agrowisata showfarm sebagai upaya pelaksanaan trilogi pembangunan terutama penunjang pertumbuhan ekonomi yang didukung oteh sumber daya alam yang memadai dan harus dikelola dengan manajemen yang baik. Dalam hal ini perlu diamati tentang pemanfaatan sumber daya alam bagi pengembangan pariwisata yaitu unsur-unsur sumber daya alam apa saja yang terkait dalam rangka pengembangan agrowisata. Bidang agrowisata mempunyai peranan penting dalam perekonomian Nasional dan regional, baik sebagai sumber devisa negara maupun sumber lapangan kerja bagi masyarakat kota dan desa memperkenalkan alam dan nilai budaya bangsa.Agrowisata dalam negeri terus dikembangkan dan diarahkan untuk memupuk rasa cinta tanah air dan bangsa serta menanamkan jiwa, semangat dan nilai-nilai luhur bangsa 
dalam rangka memperkokoh persatuan dan kesatuan Nasional disamping untuk meningkatkan kegiatan ekonomi. Salah satu sumber daya alam yang sedang mengalami pengembangan untuk mejadi objek wisata yaitu Pembangunan Agrowisata Showfarm di Kecamatan Ulu Ere Kabupaten Bantaeng. Merujuk pada hasil penelitian nampak bahwa tanggapan masyarakat terhadap program agrowisata showfarm sambut dengan baik oleh masyarakat meskipun itu membawa perubahan sosial kepada masyarakat.Kegiatan pengembangan agrowisata yang banyak mendatangkan keuntungan materi dan membuka peluang kerja, tidak boleh dinilai dari satu sisi saja, khususnya sisi ekonomi, karena kegiatan pariwisata juga mampu memperkenalkan gaya hidup dan nilai-nilai baru yang kadang-kadang terasa asing bagi penduduk setempat.

Pengembangan agrowisata sangat identik dengan tujuan untuk menarik wisatawan agar lebih banyak lagi berkunjung. Pelengkapan fasilitas-fasilitas yang menunjang kenyamanan para wisatawan dan perluasan kawasan wisata merupakan kontruksi utama agar tempat wisata lebih menarik lagi. Agrowisata merupakan suatu kegiatan perjalanan yang dilakukan dari satu tempat ke tempat lain untuk sementara waktu dengan tujuan rekreasi dan bukan untuk mencari nafkah. Jadi, tujuan utama perjalanan itu adalah berhubungan dengan pertamasyaan. Disamping itu, dari pengertian itu juga diketahui bahwa orang yang melakukan perjalanan akan memerlukan berbagai barang dan jasa sejak mereka pergi dari tempat asalnya sampai di tempat tujuan dan kembali lagi ke tempat asalnya.Munculnya produk barang dan jasa ini disebabkan adanya aktivitas rekreasi yang dilakukan oleh wisatawan yang jauh dari tempat tinggalnya. Dalam hal ini mereka membutuhkan pelayanan transportasi, akomodasi, catering, hiburan, dan pelayanan lainnya. Jadi, produk industri agrowisata adalah keseluruhan pelayanan yang diterima oleh wisatawan, mulai meningggalkan tempat tinggalnya (asal wisatawan) sampai pada tujuan (daerah tujuan wisata) dan kembali lagi ke daerah asalnya. Hal ini merupakan keuntungan bagi masyarakat setempat karena mendapatkan kesempatan untuk memperoleh penghasilan tambahan dengan cara memenuhi keperluan atau kebutuhan para wisatawan.Kegiatan pengembangan agrowisata yang banyak mendatangkan keuntungan materi dan membuka peluang kerja.Dampak pembangunan agrowisata showfarm terhadap perubahan sosial ekonomi masyarakat di Kecamatan Ulu Ere Kabupaten Bantaeng meliputi memberikan peluang kerja kepada masyarakat, bisa memperkenalkan hasil pertanian, sebagian masyarakat yang mempunyai tambahan penghasilan sehingga mereka mempunyai kemampuan untuk melanjutkan pendidikan ke jenjang yang lebih tingggi dan berinvestasi serta kesadaran pelestarian lingkungan. 
Pada masyarakat Kecamatan Ulu Ere setelah mereka mendapatkan penghasilan tambahan dengan bervariasinya pekerjaan mereka akibat pembangunan agrowisata showfarm mereka dapat menyekolahkan anak-anaknya atau memberikan kesempatan pendidikan kepada anak-anaknya agar dapat menatap atau mendapatkan masa depan yang lebih baik dari orang tuanya. Ini merupakan suatu bentuk usaha dari orang tua atau masyarakat petani yang mengelola agrowisata showfarm yang dilakukan demi masa depan anak-anaknya.Menurut Manurung sesuai perkembangan, kepariwisataan seharusnya bertujuan memberikan keuntungan baik bagi wisatawan maupun warga setempat. Pariwisata dapat memberikan kehidupan yang standar kepada warga setempat melalui kuntungan ekonomi yang didapat dari tempat tujuan wisata. Dalam tambahan, perkembangan infrastruktur dan fasilitas rekreasi, keduanya menguntungkan wisatawan dan warga setempat, sebaliknya kepariwisataan dikembangkan melalui penyediaan tempat tujuan wisata. Hal tersebut dilakukan melalui pemeliharaan kebudayaan, sejarah dan taraf perkembangan ekonomi dan suatu tempat tujuan wisata yang masuk dalam pendapatan untuk wisatawan akibatnya akan menjadikan pengalaman yang unik dari tempat wisata. Pada waktu yang sama, ada nilai-nilai yang membawa serta dalam perkembangan kepariwisataan. Sesuai dengan panduan, maka perkembangan pariwisata dapat memperbesar keuntungan sambil memperkecil masalah-masalah yang ada.

\section{KESIMPULAN}

Setelah melakukan penelitian, maka peneliti dapat menyimpulkan beberapa kesimpulan untuk menjawab masalah yang diangkat dalam penelitian ini, kesimpulan yang dapat ditarik yaitu tanggapan masyarakat Kecamatan Uluere Kabupaten Bantaeng tentang pembangunan Agrowisata Showfarm disambut baik dan diterima dengan baik oleh masyarakat meskipun itu membawa perubahan kepada masyarakat dan dampak yang ditimbulkan dari pembangunan Agrowisata Showfarm yaitu membawa dampak positif kepada masyarakat, dimana masyarakat sangat senang dengan keberadaan Agrowisata yang dibangun oleh pemerintah untuk masyarakat.

\section{DAFTAR PUSTAKA}

About Agritourism at http://www.farmstop.com/aboutagritourism.asp (diunduh pada 15 Maret 2015)

Anonim. (2004). "potensi agrowisata”. Pada http://lampung post.com/berita (diunduh pada tanggal 18 Maret 2015) 
Ariyanto,Rudy. (2003). Ekonomi Pariwisata Jakarta: pada http://www.geocities.com/ Ariyantoeks 7/home.htm (diundu pada tanggal 18 Maret 2015)

Asdiar. (2010). Skripsi. (Pandangan Keluarga Pemulung Terhadap Pendidikan Formal di Kecamatan Sinjai Utara Kabupaten Sinjai). Makassar : Unismuh.

Azhari Eka Putra. (2010). Skripsi. (Dampak Pengembangan Objek Wisata Pada Masyarakat Kelurahan Ekatiro Kecamatan Bontotiro)Makassar : Unismuh.

Deptan, (2005) ."Agrowisata Meningkatkan Pendapatan Petani",http://www.database.deptan.go.id (diakses pada tanggal 18 Maret 2015)

Fakih Mansour. (2011).Sesat Pikir Teori Pembangunan dan Globalisasi:Insint press.

James Zanden W. Vander (1990) .Sosial. Experiences an introduction tosociology.mc.grow-hill:New York

Lexy J. Maleong. (2007). Metode Penelitian Kualitatif. Bandung: PT Remaja Rosdakarya

M.Z. Lawang Robert . (2006). Teori Sosiologi Klasik dan Modern. Jakarta:Gramedia Group.

Manurung, Happy. (2002). Pengetahuan Kepariwisataan. Bandung : Alfa Beta

Nawawi, H. Handari. (2005). Metode Penelitian Bidang Sosial.Yogyakarta: Gajah Mada Universitas Vers

Piotr Sztompka. (2007). Sosiologi Perubahan Sosial. Jakarta:Prenada Media Group.

Raharjo Mudjia. (2000). Sosiologi Pedesaan Studi Perubahan Sosial. Malang UIN: Malang Press.

Salam Syamsir dkk. (2008). Sosiologi Pedesaan. Jakarta: Lembaga Penelitian UIN

SetiadiElly M. dkk . (2006)Ilmu sosial dan budaya dasar, Jakarta: Prenada Media Group

Shadily, Hasan. (1963). Sosiologi Untuk Masyarakat Indonesia. Jakarta:PT.Pembangunan

Soekanto Soerjono. (2009). Sosiologi Suatu Pengantar. Jakarta: PT.Raja Grapindo Persada.

Suharsaputra, Uhar. (2012) . MetodePenelitian Kuantiatif,Kualitatif, dan Tindakan. Bandung: Refika Aditama

Sutjipta. (2001). http//: www.google.co.id/Sutjipto/ekowisata_agrowisata.html (diakses pada tanggal 15 Maret 2015)

Tiro, Muhammad Arif. (2005). Metode Penelitian Sosial-Keagamaan.Penerbit Publisher 
U.S. Konggres OTA. (1992). http://www.database.depta.go.id (diakses pada tanggal 15 maret 2015)

Yoeti, Oka A. (1992). Pengantar Ilmu Pariwisata. Bandung : Angkasa. 